\title{
Profiles of Supportive Alumni: Donors, Volunteers, and Those Who "Do It All"
}

Received (in revised form): March 13, 2007

\section{David J. Weerts}

is Assistant Professor of Higher Education at Florida Atlantic University in Boca Raton, Florida and faculty affiliate at the Wisconsin Center for the Advancement of Postsecondary Education (WISCAPE), University of Wisconsin-Madison.

\section{Justin M. Ronca}

is Research Associate at the Wisconsin Center for the Advancement of Postsecondary Education (WISCAPE), University of Wisconsin-Madison and doctoral student in the Department of Statistics at UW-Madison.

\begin{abstract}
In the competitive marketplace of higher education, college and university alumni are increasingly called on to support their institutions in multiple ways: political advocacy, volunteerism, and charitable giving. Drawing on alumni survey data gathered from a large research extensive university, we employ a multinomial logistic regression model to distinguish characteristics of inactive alumni from those who give, volunteer, or give and volunteer at their alma mater. Economic, social exchange, expectancy, and investment theories
\end{abstract}

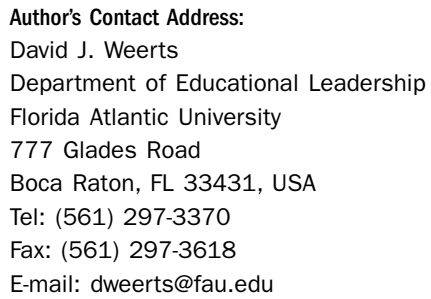

shed light on lifecycles, attitudes, and lifestyles associated with alumni giving and voluntary support for higher education.

International Journal of Educational Advancement (2007) 7, 20-34. doi:10.1057/palgrave.ijea.2150044

\section{Keywords:}

alumni, donor characteristics, social exchange theory

\section{Introduction}

Scholarly interest on alumni giving to colleges and universities in the United States continues to grow. Over the past two decades, researchers have tested a wide array of variables to identify the most important factors predicting alumni giving to their alma maters. Research on alumni giving is typically divided into four distinct topical areas: individual donor characteristics, fundraising practices, external environment, 
and institutional characteristics

(Gunsalus, 2004).

While important contributions have been made to the study of alumni support for higher education, much of this work has focused solely on charitable giving. In the increasingly competitive marketplace of higher education, colleges and universities are examining new ways to leverage the influence of their graduates beyond their checkbook. For example, alumni advocates who help their institutions to secure taxpayer support for higher education have become important players in the state lobbying process (Koral, 1998).

Alumni influence is critical to institutions because professional and personal connections held by graduates can open doors to the legislature, governor's office, corporations, foundations, and major gift prospects. In addition, alumni members of college advisory boards lend their experiences and expertise to help higher education leaders formulate strategic directions for their institutions (Weerts, 1998). Alumni volunteers also serve in other important ways such as mentors, recruiters, and booster club leaders that raise the profile of the institution in their region.

\section{Purpose of this Study}

Our study takes a comprehensive view of alumni support by examining variables associated with multiple modes of alumni support for higher education-financial support, volunteer service, and political advocacy. The research question guiding our study is, "What variables distinguish between alumni who do not support their alma mater through charitable giving and/or volunteering, compared to those who financially support the institution, serve as volunteers, or give and volunteer?" Put simply, this study aims to create a profile of "supportive" university alumni who are likely to be generous in the use of both their time and money. As such, we aim to further the development of theories related to alumni involvement in higher education and provide institutional leaders with a more robust model to identify alumni who have the capacity and inclination to contribute to their alma mater in multiple ways.

\section{Literature Review and Conceptual Framework} Drawing on alumni giving literature, economics, and theories of motivation, we propose a conceptual model suggesting characteristics of alumni donors who are likely to give and volunteer at their alma mater. We build on Volkwein et al.'s (1989) theoretical framework suggesting that alumni support is a function of demographic background, college experiences, and college outcomes that form alumni capacity and inclination to support their alma mater. The key constructs of capacity and inclination are examined below.

\section{Capacity to Give and Volunteer}

Giving capacity variables are well documented in the literature. Alumni giving capacity is primarily determined by availability of financial resources (Connolly and Blanchette, 1986) and influenced, in part, by key demographic variables: family size, and the ages and schooling of children and grandchildren. As age increases and 
families mature, so does capacity and the likelihood of increased philanthropic contributions to their alma mater (Pendel, 1985; Connolly and Blanchette, 1986; Hueston, 1992). Many studies suggest that giving is associated with occupation, increases in age and household income (Olsen et al., 1989; Baade and Sundberg, 1996; Belfield and Beney, 2000; Wunnava and Lauze, 2001; Clotfelter, 2003; Monks, 2003; Thomas and Smart, 2005).

Some studies suggest that giving is associated with an alum's level of financial burden in funding their undergraduate education. For example, one study showed that need-based loans recipients gave less to the institution, while alumni donors who had an academic scholarship while in college increased their gift size (Dugan et al., 2000). In addition, Monks (2003) learned that alumni who gave less to their alma mater had loan debt. These studies suggest that capacity and inclination may be shaped by complex socio-economic factors.

Regarding volunteerism, the Bureau of Labor indicates that women volunteer at a higher rate than men across age groups, education levels, and other major characteristics (Bureau of Labor Statistics, 2004). These gender differences are consistent with research on higher education philanthropy indicating that women may volunteer more than men as it relates to their philanthropy (Shaw and Taylor, 1995). Overall, research suggests that women may be more generous with their time and money than men (Philanthropic Research Inc., 1996).

In addition, age and lifecycle have important implications for volunteerism. According to recent data from the Bureau of Labor Statistics, persons aged 35-44 are most likely to volunteer, and volunteer rates are lowest among persons in their early 20 s or over 65 . In addition, married persons typically volunteer at a higher rate than never married persons, and people who were employed volunteered at a higher rate than those who were unemployed or not in the labor force (Bureau of Labor Statistics, 2004).

Overall, lifecycles play a significant role in changing patterns of time use and are based on four factors: age, marital status, presence of children, and employment status (Zuzanek and Smale, 1999). An analysis of time is important in the context of alumni volunteerism because it suggests that certain lifestyle patterns lead to activities that may either promote or "crowd out" opportunities to volunteer at the university. For example, alumni donors may be lured to support new charities independent of their relationship with the university. The presence of these alternatives may limit opportunities for giving and volunteering at the institution.

A contrasting theory, however, is that alumni who give and volunteer to their alma mater are generally more philanthropically inclined, and thus more likely to give to a number of organizations. This opposing viewpoint is supported by research that links alumni giving to higher education to philanthropic support for civic organizations (Miracle, 1977; House, 1987).

\section{Inclination to Give and Volunteer}

In this study, motivation for giving and volunteering draws on three 
conceptual models that are theoretically relevant to the literature on alumni support: social exchange theory, expectancy theory, and the investment model.

\section{Social exchange theory}

Social exchange theory assumes that relationships are "give and take" among partners. In sum, this theory suggests that relationships are thought about in economic terms and that costs and benefits are weighed to determine whether the relationship will continue (Chadwick-Jones, 1976). Applied to this study, social exchange theory suggests that the "cost" of financial or volunteer support for an institution is weighed against the benefits the alum has received from the university in the past or present (e.g., quality of education, career gains, social connections and prestige).

Social exchange theory is supported by a number of studies concluding that alumni support is associated with the alum's perceptions about the value of his or her current and past experiences with the institution. For example, a number of studies link alumni giving to involvement in extracurricular activities while an undergraduate student (see Keller, 1982; Haddad, 1986; Harrison et al., 1995; Dugan et al., 2000; Monks, 2003).

Beyond extracurricular activities, the quality of the academic experience itself is associated with alumni support. Studies suggest that alumni giving is associated with mentoring in college (Clotfelter, 2003), favorable faculty/student ratio and strong academic reputation (Cunningham and Cochi-Ficano, 2001), frequent contact with faculty and staff (Monks, 2003), and overall graduation rates (Gunsalus, 2004).

In general, there is a strong connection between giving and how alumni view their alma mater, the degree of satisfaction with their alumni experience, and their level of engagement in alumni activities (Miracle, 1977; Loessin et al., 1986; Caboni, 2003; Clotfelter, 2003; Monks, 2003). These factors influence the social exchange relationship and the extent to which alumni will give and volunteer at the institution.

\section{Expectancy theory}

The second model in this study, expectancy theory, argues that alumni have expectations about future events and that their giving and volunteer behavior reflects these expectations. Alumni support in this model is based on whether the alum feels that he or she can make a difference to the organization through charitable gifts or volunteer service. Adapted from Vroom's (1964) classic work, motivation in this case is based on three factors: (1) Valence: the value or perceived outcome of the support, (2) Instrumentality: the belief that support (time and/or money) will help the university achieve a certain outcome, and (3) Expectancy: that the alumnus feels capable of making a financial or time commitment. In sum, alumni will give and volunteer if they believe that there is a positive relationship between their efforts, performance, and a desirable outcome.

Our study posits that institutions play a major role in shaping expectations of alumni, and that alumni make decisions about giving and volunteering, in part, based on 
these expectations. For example, it is widely known that institutions expend significant time and money to manage the expectations of alumni through a variety of mediums that solicit and/or encourage giving and volunteerism (Harrison, 1995). Studies suggest that development effort-expenditures on alumni and development programs-is associated with increases in alumni giving (Leslie and Ramey, 1988; Harrison, 1995; Baade and Sundberg, 1996; Okunade, 1996).

Overall, alumni must be convinced that the institution needs their support before they will make a decision to give or volunteer. For instance, the variable, "perceived need for financial support" has been shown in many studies to be an important predictor of alumni giving (Miracle, 1977; House, 1987; Taylor and Martin, 1995; Diamond and Kashyap, 1997). Similarly, Pearson's (1999) research found that a significant deterrent to giving is a feeling among alumni that the university does not need their gifts as much as other nonprofit organizations. Expectancy theory in this study argues that alumni donors decide whether it is worthwhile to give or volunteer, in part, due to the presence or absence of institutional messages making a case for support.

\section{Investment model}

Finally, increased gift levels may also be explained by the investment model. Rusbult (1980) articulated the components of the investment model noting that an individual's commitment to a relationship is a function of outcomes (rewards and costs), the magnitude of the individual's investment in that relationship, and quality of the best available alternative to this relationship. She argues that "commitment increases with the passage of time in part because the resources put into a relationship increase the costs of withdrawing from it" (p. 174). Investments can be extrinsic-linked to external gains or losses-or intrinsic which is comprised of time, emotional involvement, or money.

While Rusbult's work examines personal relationships, the investment model is well suited to the context of understanding alumni giving and volunteer behavior. This suggests that additional alumni giving depends on (1) satisfaction level with the balance of rewards and costs in the relationship, (2) the extent that alum has already invested in the relationship, and (3) a comparison with potential alternative relationships. Investments may include financial, time, and emotional investments in the organization.

A wealth of evidence suggests that the investment model is a compelling framework for examining whether alumni will increase their levels of giving to the university. For example, emotional attachment and investment with the university has been shown to be an important factor predicting alumni giving (Gardner, 1975; Beeler, 1982; Shadoian, 1989). Mael and Ashforth (1992) suggest that donors who are emotionally attached establish a "perception of oneness with or belongingness to an organization where the individual defines him or herself in terms of the organizations in which he is a member" (Caboni, 2003, p. 6). In general, volunteering at the college or institutional level is associated with alumni giving to the 
university (Taylor and Martin, 1995; Wunnava and Lauze, 2001; Clotfelter, 2003) and alumni who have long intensive experiences with their alma mater are likely to be more generous to the institution (Korvas, 1984).

Independent of these connections, alumni donors may invest in the university for other reasons. For example, family legacies add significant financial, time, and emotional investment in a campus. The presence of these family ties to institutions is associated with alumni giving (Okunade and Berl, 1997; Wunnava and Lauze, 2001).

\section{Methodology}

The conceptual framework outlined above informs our methodology to identify characteristics of alumni who are disengaged with supporting their alma mater, are active volunteers, active donors, or active donors and volunteers. This analysis will not attempt to establish a causal relationship between alumni characteristics and levels or types of alumni involvement; instead, it will highlight characteristics identified in our conceptual framework which tend to be present in alumni who fall into one of four categories: INACTIVE, VOLUNTEER, DONOR, and SUPPORTER.

INACTIVE refers to alumni who have no record of giving or volunteering at their alma mater. VOLUNTEER is defined as an alumnus who has supported the institution through one or more service roles. These roles include, but are not limited to, alumni club leader, political advocate, or on a college advisory board. DONOR is an alumnus who has financially supported the university but has not volunteered as defined above. Finally, SUPPORTER refers to an alumnus who has served as both a volunteer and donor as defined above.

\section{Data}

The data for this analysis are drawn from an alumni survey conducted at a Doctoral/Research University-Extensive as defined by the 2000 Carnegie Classification definitions. The institution is referred to as Research Extensive University (REU) for the remainder for this study. The survey was sent to 2,400 alumni of REU between the ages of 30 and 70 . The survey was stratified based on sex, age, and membership in key alumni organizations. We use inclusion weights in our analysis to account for the nonrandom nature of the survey sampling protocol. Of the 2,400 alumni surveyed, 1,441 responded. The response rate was approximately 60 percent. Data collected allowed us to classify respondents into one of the four categories explained above: INACTIVE, VOLUNTEER, DONOR, or SUPPORTER. Our dependent variable is defined as ALUMSTAT “Alumnus Status" which is a factor variable comprised of the four nominal levels. Criteria used to categorize these variables are illustrated in Figure 1.

Based on our conceptual framework, we defined 15 independent variables of interest and constructed them using data captured by the questions posed in our survey. These variables are illustrated in Figure 2. 


\begin{tabular}{l|l|}
\hline & \multicolumn{1}{c|}{ CRITERIA FOR INCLUSION } \\
\hline VOLUNTEER & $\begin{array}{l}\text { Serve in one or more of the following capacities: } \\
\text { - School/college/department advisory board, board of visitors } \\
\text { - Club officer/volunteer for local/national chapter of REU alumni association } \\
\text { - Host REU Foundation events in your area } \\
\text { - Mentor new REU alumni (e.g., REU career volunteer program) } \\
\text { - Assist with special events (REU charity run/walk) } \\
\text { - Contact legislator/Governor's office on behalf of REU (e.g., member of } \\
\text { REU political action network) }\end{array}$ \\
\hline DONOR & - Made a charitable gift to REU (cash, stock, land, real estate, other) \\
\hline SUPPORTER & $\begin{array}{l}\text { - Serve in one or more of capacities listed in VOLUNTEER } \\
\text { - Made a charitable gift to REU (cash, stock, land, real estate, other) }\end{array}$ \\
\hline INACTIVE & - Never volunteered or made a charitable gift to REU \\
\hline
\end{tabular}

Figure 1: Dependent variables.

\section{Variables and Expected Relationships}

The variables discussed in our conceptual framework suggest a number of expected relationships. Informed by our review of literature, we articulate these expected relationships in Figure 3 below.

We specify a weighted nominal multinomial logistic regression model using maximum likelihood estimation in an effort to address the posited research question. We assume the responses of the dependent variable to have a nominal ordering as there is no clear trade-off between volunteer activities and donor status. For example, an alumnus who never supports the institution financially, but who is a strong political advocate for his or her alma mater, may prove to be even more valuable to the institution than an individual who makes modest annual contributions.

We use design weights in order to account for the complex stratification scheme used by REU in its sampling protocol. Design weights account for the fact that the probability of selection varies between strata due to differences in stratum size. We scale the weights vector so that the sum of the weights is equivalent to the length of each $x$-vector after missing observations are deleted. After deleting missing observations, we have a sample size of 879 alumni. By scaling the weights, we avoid an unwarranted deflation of the standard errors associated with our parameter estimates.

If a respondent did not answer one of the questions used to define each of the 17 variables included in our full model, we deleted that observation, listwise, from the data set instead of imputing its value. This results in a sample of 879 complete observations.

\section{Findings}

After fitting the full model, we noted that a number of the predictors were insignificant at an alpha level of 0.05. Therefore, we employed a forwardbackward stepwise model selection routine in which we used the Bayesian Information Criterion (BIC) to facilitate variable selection. The model with the smallest BIC score contained only four variables. We then computed 


\begin{tabular}{|c|c|c|}
\hline Variable family & Theory of alumni support & Survey variables examined \\
\hline \multirow[t]{2}{*}{ Capacity variables } & $\begin{array}{l}\text { Alumni giving and volunteerism is } \\
\text { predicted by lifecycle or } \\
\text { demographic characteristics. }\end{array}$ & $\begin{array}{l}\text { SEX: } 1=\text { female, } 0=\text { male. } \\
\text { AGE: Age in years of the respondent. } \\
\text { EMPSTAT: "Employment status" } 1=\text { active in the labor market, } 0= \\
\text { otherwise. } \\
\text { MARSTAT: "Marital Status" } 1=\text { married prior to survey completion, } \\
0=\text { otherwise. } \\
\text { HOUSEINC: "Household Income" Eleven income categories were } \\
\text { provided in the survey. }\end{array}$ \\
\hline & $\begin{array}{l}\text { Alumni giving and volunteerism } \\
\text { depends on availability of time and } \\
\text { financial support that can } \\
\text { distributed among competing non- } \\
\text { profit groups. }\end{array}$ & $\begin{array}{l}\text { CRFIN: "Civic or Religious Financial Commitments". Composite } \\
\text { variable indicating their level of financial support for religious } \\
\text { organizations, neighborhood groups, charitable or voluntary service } \\
\text { groups, United Way Agencies, political organizations, partisan groups, } \\
\text { causes to cure diseases, and social or fraternal organizations. } \\
\text { CRVOL: "Civic or Religious Commitments". Composite variable } \\
\text { indicating their level of volunteer support for organizations defined } \\
\text { above in CRFIN. }\end{array}$ \\
\hline \multirow[t]{3}{*}{ Inclination variables } & $\begin{array}{l}\text { Social exchange theory: Alumni } \\
\text { support is based on a feeling about } \\
\text { whether a balance exists between } \\
\text { what is put into the effort and what } \\
\text { has been received from the } \\
\text { university in the past or present. }\end{array}$ & $\begin{array}{l}\text { ACENG: "Academic Engagement". Composite variable calculating } \\
\text { the level of academic engagement experienced as an undergraduate-- } \\
\text { interaction with individual faculty and staff, exposure to diverse points } \\
\text { of view, intellectual rigor of their academic programs. } \\
\text { SOCENG: "Social Engagement". Composite variable calculating the } \\
\text { level of social engagement experienced as an undergraduate- } \\
\text { participation in academic, professional, or social organizations. } \\
\text { FINRATIO: "Ratio of Financial Burden." Ratio of the student's } \\
\text { financial burden in financing his/her education compared to the burden } \\
\text { borne by "others." Personal burden: the extent to which alumnus } \\
\text { funded own education through employment and student loans. Non- } \\
\text { personal burden: extent to which the alumnus' education was financed } \\
\text { by scholarships, grants, and support from family members. }\end{array}$ \\
\hline & $\begin{array}{l}\text { Expectancy theory: Alumni have } \\
\text { expectations about the value of } \\
\text { their support and these } \\
\text { expectations predict their future } \\
\text { involvement in the university. } \\
\text { Institutions shape these } \\
\text { expectations. }\end{array}$ & $\begin{array}{l}\text { EXTEFF: "External Relations Effort". Whether alumnus had been } \\
\text { solicited for gifts or volunteer support by REU. 1= alumnus had been } \\
\text { solicited 0= no solicitation } \\
\text { ALUMATT: "Alumni Attitudes". Measured on a 5-point likert scale, } \\
\text { level of agreement with each of the following statements: 1) Alumni } \\
\text { should support their alma mater through charitable contributions. 2) } \\
\text { Alumni should support their alma mater through volunteer service. 3) } \\
\text { My alma mater needs my political advocacy. 4) My alma mater needs } \\
\text { my volunteer service. }\end{array}$ \\
\hline & $\begin{array}{l}\text { Investment model: Alumni } \\
\text { support is based on the extent of } \\
\text { time, emotion, and financial } \\
\text { commitment already invested in } \\
\text { the university. }\end{array}$ & $\begin{array}{l}\text { MULGEN: "Multiple generations with same alma mater". Measure } \\
\text { of whether alumnus had one or more children who had attended REU. } \\
\text { 1= one or more children have attended REU, } 0=\text { otherwise. } \\
\text { DEGREECNT: "Degree Count". Number of degrees, beyond a } \\
\text { bachelor's degree, that respondent earned from REU. Four possible } \\
\text { answers: } 0 \text { additional degrees, } 1 \text { additional degree, } 2 \text { additional } \\
\text { degrees, } 3 \text { or more additional degrees. } \\
\text { AICON: "Alumni-Initiated Connection". Whether had attended } \\
\text { events or visited REU since graduation: commencement/awards } \\
\text { ceremony, athletic events, cultural events, libraries, student union. } \\
\text { The respondent could select as many as were applicable. } \\
\text { Variable range: } 0 \text { to } 6 \text {. }\end{array}$ \\
\hline
\end{tabular}

Figure 2: Alumni support variables tested from conceptual framework.

the squared Wald statistic associated with each predictor. A squared Wald statistic for an individual coefficient estimate follows a chi-square distribution with one degree of freedom. We include all predictors that are significant at one or more levels of the response variable. Therefore, in order to ensure 95 percent family confidence, with respect to at least one level of the response variable, we compare the squared Wald statistics 


\begin{tabular}{|c|c|}
\hline Variable family & Survey variables \\
\hline \multirow[t]{2}{*}{$\underline{\text { Capacity variables }}$} & $\begin{array}{l}\text { SEX: We expect that female alumni will be more likely to give and volunteer than male alumni. } \\
\text { AGE: We expect giving to be positively correlated with increases in age. We forecast that REU } \\
\text { alumni volunteers will be middle aged and less likely to be in their } 20 \text { o or over } 65 \text {. } \\
\text { EMPSTAT: "Employment status" We expect that likelihood of giving and volunteering will be } \\
\text { positively associated with full time employment status. } \\
\text { MARSTAT: "Marital Status" We expect that REU alumni who are married will be more likely to give } \\
\text { and volunteer than unmarried alums. } \\
\text { HOUSEINC: "Household Income" We expect that likelihood of giving will increase with } \\
\text { increased levels of household income among REU alumni. }\end{array}$ \\
\hline & $\begin{array}{l}\text { CRFIN: "Civic or Religious Financial Commitments" } \\
\text { CRVOL: "Civic or Religious Volunteer Commitments" } \\
\text { For both variables above, we test conflicting hypotheses. First, we posit that additional giving or } \\
\text { volunteer commitments "crowd out" opportunities to give to REU. Alternatively, we test past } \\
\text { research suggesting that gift commitments to civic organizations are positively associated with } \\
\text { giving to higher education institutions. }\end{array}$ \\
\hline$\underline{\text { Inclination variables }}$ & $\begin{array}{l}\text { ACENG: "Academic Engagement" We expect that alumni who report higher levels of academic } \\
\text { engagement while an undergraduate student will be more likely to give and volunteer. } \\
\text { SOCENG: "Social Engagement" We expect that alumni who report higher levels of social } \\
\text { engagement while an undergraduate student will be more likely to give and volunteer. } \\
\text { FINRATIO: "Ratio of Financial Burden." We expect that alumni who have had less personal } \\
\text { burden in financing their undergraduate education (received family support, scholarships, loans, } \\
\text { etc.) will be more likely to give and volunteer than those who had more personal burden (loans, } \\
\text { employment). }\end{array}$ \\
\hline Expectancy theory & $\begin{array}{l}\text { EXTEFF: "External Relations Effort". We expect that the likelihood of alumni giving and } \\
\text { volunteerism will increase with increased institutional solicitation for giving and volunteerism. } \\
\text { ALUMATT: "Alumni Attitudes". We expect that the likelihood of alumni giving and } \\
\text { volunteerism will increase with increased level of agreement with the following four statements: } \\
\text { 1) Alumni should support their alma mater through charitable contributions. 2) Alumni should } \\
\text { support their alma mater through volunteer service. 3) My alma mater needs my political } \\
\text { advocacy. 4) My alma mater needs my financial support. 5) My alma mater needs my volunteer } \\
\text { service. }\end{array}$ \\
\hline Investment model & $\begin{array}{l}\text { MULGEN: "Multiple generations with same alma mater" We expect that alumni who have had } \\
\text { one or more children attend REU will be more likely to give and volunteer. } \\
\text { DEGREECNT: "Degree Count". We expect that the likelihood of alumni giving and } \\
\text { volunteering will increase with the number of degrees an alum earns at REU. } \\
\text { AICON: "Alumni-Initiated Connection". We expect that alumni who attend REU events or have } \\
\text { visited REU since graduation will be more likely to give and volunteer. }\end{array}$ \\
\hline
\end{tabular}

Figure 3: Expected relationships based on conceptual framework.

against a chi-square value of 6.24. In the three columns titled "Signif," we note whether or not each coefficient is statistically significant; indeed, all four covariates were significant at one or more levels. Each of the four covariates in the final model is statistically significant with respect to at least one of the levels in the dependent variable. Our final model appears in Table 1 .

\section{Discussion}

Our model suggests a small, but powerful, group of variables distinguish between REU alumni who are likely to be "inactive" versus "supportive" of their alma mater through giving and/or volunteering. Each of these variables will be discussed in the context of the conceptual framework outlined earlier in this study. 
Capacity to give and/or volunteer Our study illustrates the importance of life stage in predicting alumni giving and volunteer support for higher education. In particular, the age of the alumnus is an important variable predicting alumni support at REU. For each unit increase in age, an REU alumnus is 1.09 times more likely to volunteer at the institution. Alums that fell into the SUPPORTER category (alumni who give and volunteer) had an identical increase in probability based on age. These findings contrast data from the Bureau of Labor suggesting that middle age people are more likely to volunteer than older individuals. Our alternative findings may speak to the selective nature of volunteer roles available at colleges and universities compared to more local organizations. For example, coaching youth soccer requires less "clout" than seasoned alumni advisory board members who may be tapped for their power and influence.

Influential alumni are more likely to be older and firmly established in their careers.

In addition to age, employment status is a critical variable distinguishing alumni who were most likely to fall in the DONOR or SUPPORTER category. Holding all other variables constant, alumni who are employed are 1.8 times more likely to give compared to those who do not support the institution financially. Even more dramatic, alumni who give and volunteer (SUPPORTER) are 12.71 times more likely to be employed than INACTIVE alums. Again, our findings may reflect the selective nature of volunteer roles available at colleges and universities. Alumni who are employed are more likely to have 
access to stronger networks of influential people or organizations of interest to colleges and universities. As for giving capacity, our findings support past literature suggesting that alumni giving is associated with employment and household income.

\section{Inclination to give and/or volunteer}

The expectancy model emerged as the most powerful inclination theory in our analysis of volunteers, donors, and supportive alumni. Holding other variables constant, alumni in the SUPPORTER category were 9.28 times more likely to give and volunteer based on a one unit increase in agreement with the following two statements: (1) Alumni should support their alma mater through charitable giving and volunteering, (2) REU needs my volunteer and financial support. Similarly, alumni in the DONOR category were 2.88 times more likely to give per unit increase with statements affirming REU financial needs and alumni roles in giving.

These findings suggest that alumni donors who are likely to give and volunteer at their alma mater expect to be involved in supporting the institution. In addition, they have developed a view that the institution needs their support. What remains unclear is the source responsible for developing these views. For example, to what extent did the university (past or present) play a role in shaping these expectations among alumni? The external relations effort variable tested in this study (EXTEFF) was not significant, suggesting that alumni increases in giving levels is not strongly tied to fund-raising solicitations by
REU. Given this finding, we are uncertain what is responsible for molding these expectations.

While additional research is needed, an alternative theory is that alumni decisions to give and volunteer may be more closely aligned with personal values about philanthropy and volunteerism rather than institutional efforts to cultivate support. These attitudes might have been developed through their upbringing or other life experiences that cultivated a "giving or service ethic" for higher education. For example, Volkwein et al. (1989) suggest that demographic variables such as parents' level of educational attainment may predict motivation for giving among alumni. In other words, if an alumnus comes from a family that values higher education, the individual may be more inclined to support it with their philanthropy. Regardless of the reason, an important implication is that advancement officers must clearly communicate with alumni about institutional needs and the role they might play in meeting these needs.

Investment theory is another compelling construct in our model. A distinguishing characteristic between SUPPORTER and INACTIVE alumni is the level of contact an alumnus initiates with the institution pursuant to social and cultural opportunities. Specifically, SUPPORTER alumni of REU are 1.53 more times more likely than INACTIVE alumni to have attended athletic events, cultural activities, awards ceremonies, or visited campus libraries or the student union since graduation. These findings suggest that the most committed alumni (SUPPORTER) have chosen to make the institution an important part of their life after graduation. Their 
Table 2: Characteristics of alumni volunteers, donors, and supporters

\begin{tabular}{|c|c|c|c|c|}
\hline Variable family & $\begin{array}{l}\text { Theory of alumni } \\
\text { support }\end{array}$ & VOLUNTEER & DONOR & SUPPORTER \\
\hline Capacity variables & $\begin{array}{l}\text { Lifecycle or } \\
\text { demographic } \\
\text { characteristics }\end{array}$ & $\begin{array}{l}\text { - Age (probability } \\
\text { increases with } \\
\text { age) }\end{array}$ & - Employed & $\begin{array}{l}\text { - Age (probability } \\
\text { increases with age) } \\
\text { - Employed }\end{array}$ \\
\hline Inclination variables & Expectancy theory & & $\begin{array}{l}\text { - Believes REU needs } \\
\text { their financial } \\
\text { support } \\
\text { - Believes alumni } \\
\text { should play a role } \\
\text { in supporting the } \\
\text { institution financially }\end{array}$ & $\begin{array}{l}\text { - Believes REU needs } \\
\text { their volunteer and } \\
\text { financial support. } \\
\text { - Believes that alumni } \\
\text { should play a role } \\
\text { in giving and } \\
\text { volunteering. } \\
\text { - Initiates connections } \\
\text { to campus (social, } \\
\text { cultural, recreational) }\end{array}$ \\
\hline
\end{tabular}

personal initiative to stay connected indicates an emotional attachment to the university and is reflected in their giving and volunteerism.

Finally, it was somewhat surprising to the researchers that variables representing social exchange theory were not significant in the final model. Instead, our data revealed a wide variance of academic and social experiences (ACENG, SOCENG) among REU alumni. In other words, INACTIVE alumni were just as likely to report strong academic and social experiences as those listed in the other categories. Thus, we conclude that student engagement in college does not necessarily translate into dollars or volunteer time. These findings make sense on a practical level. Across the country, many alums report strong undergraduate experiences at their alma mater. A much smaller percentage, however, give or volunteer at the institution. As a result, "other" factors-such as the ones we have identified in this paper-may be more compelling to explain alumni giving and volunteer support. A summary of our findings and their connection to our conceptual framework is found in Table 2.

\section{Conclusions and Notes for Practitioners}

Our study provides some important implications for advancement practitioners. An important observation is that there are many factors outside of the control of institutional leaders that predict alumni giving and volunteerism for higher education. For example, alumni support is highly correlated with increases in age and the employment status of the graduate. On the surface, this suggests that advancement officers must wait for alumni to mature like "fine wine" before they are ready to be enlisted as donors and volunteers. On the other hand, this finding may simply reflect the fact that alumni who are targeted for giving volunteer service are more likely to be older and well 
established in their careers. For example, major gifts officers often operate on the " $80 / 20$ rule," indicating that most time and energy is spent on the top 20 percent of donors who have the greatest capacity to meet institutional needs (Sturtevant, 2002). Chances are that these top donors are older and well established in their careers.

A more interesting finding relates to the variables associated with alumni inclination to give and/or volunteer. Most important, "super" alumni (SUPPORTER) did not look significantly different compared to their INACTIVE classmates regarding academic and social engagement while in college. Instead, SUPPORTER alums are distinguished by their attitudes and expectations about university needs, and their personal responsibility to give and volunteer at the university. An important question for institutional leaders to consider is "How are these attitudes formed? Are these values cultivated at the institution or elsewhere?" These questions merit further investigation.

Finally, we suggest that alumni attitudes may be associated with our findings that SUPPORTER alums were more likely to have initiated a life long relationship with the university (by attending campus events after graduation). In other words, alumni who give and volunteer have formed deeper connections to their alma mater and this may impact their understanding about institutional needs and their role in meeting these needs. Advancement officers must establish awareness of "supporters in their backyard" who may already be involved, but have not yet been asked to get involved as a volunteer or donor.

\section{Limitations and Future Research}

There are important limitations of this study that must be acknowledged. First, caution must be taken when interpreting alumni data that was collected years after the alumnus graduated from the institution. Prior research suggests that asking alumni to recall events, some of which may have taken place several decades ago, may distort the accuracy of the actual undergraduate experiences of alumni (Pike, 1994). These words of caution apply to our study since the REU survey asked alumni to recall and rank the quality and depth of their experiences in a number of domains.

A second limitation of this study is that it is a single case study of one large research university with its own unique culture and institutional traditions. In this case, the findings may not be easily generalized to a large cadre of institutions with differing sizes and missions. Future research might test variables examined in this study's conceptual framework within a large data set representing many types of institutions.

\section{Acknowledgements}

The authors wish to thank Henry Lufler, Heidi Zoerb, and the staff of the Wisconsin Center for the Advancement of Postsecondary Education (WISCAPE) for their support of this project.

\footnotetext{
References

Baade, R.A. and Sundberg, J.O. (1996), "What determines alumni generosity?" Economics of Education Review, 15, 1, pp. 75-81.
} 
Beeler, K.J. (1982), "A study of predictors of alumni philanthropy in private universities," Doctoral dissertation, University of Connecticut.

Belfield, C.R. and Beney, A.P. (2000), "What determines alumni generosity? Evidence for the UK," Education Economics, 8, 1, pp. 65-80.

Bureau of Labor Statistics (2004), "Volunteering in the United States, 2004," Press release December 16, 2004. Available online: http://www.bls. gov/cps/.

Caboni, T.C. (2003, November 12-16), "Organizational identification and voluntary support of higher education," Paper presented at the Association for the Study of Higher Education Annual Meeting, Portland, OR.

Chadwick-Jones, J.K. (1976), Social Exchange Theory: Its Structure and Influence in Social Psychology, Academic Press, London.

Clotfelter, C.T. (2003), "Alumni giving to elite private colleges and universities," Economics of Education Review, 22, 2, pp. 109-120.

Connolly, M.S. and Blanchette, R. (1986), "Understanding and predicting alumni giving behavior," in J. A. Dunn (ed.), Enhancing the Management of Fund Raising, Jossey-Bass, San Francisco.

Cunningham, B.M. and Cochi-Ficano, C.K. (2001), "The determinants of donative revenue flows form alumni of higher education," Journal of Human Resources, 37, 3, pp. 540-569.

Diamond, W.D. and Kashyap, R.K. (1997), "Extending models of prosocial behavior to explain university alumni contributions," Journal of Applied Social Psychology, 27, pp. 915-928.

Dugan, K., Mullin, C.H. and Siegfried, J.J. (2000), "Undergraduate Financial Aid and Subsequent Alumni Giving Behavior," Williams Project on the Economics of Higher Education Discussion Papers, DP-57.

Gardner, P.M. (1975), "A study of the attitudes of Harding College alumni with an emphasis on donors and non-donor characteristics," Doctoral dissertation, Ohio State University.

Gunsalus, R. (2004), “The relationship of institutional characteristics and giving participation rates of alumni," International Journal of Educational Advancement, 5, 2, pp. 162-170.

Haddad, F.D. (1986), "An analysis of the characteristics of alumni donors and non-donors at Butler University," Doctoral dissertation, Butler University.

Harrison, W.B. (1995), “College relations and fundraising expenditure: Influencing the probability of alumni giving to higher education," Economics of Education Review, 14, 1, pp. 73-84.
Harrison, W.B., Mitchell, S.K. and Peterson, S.P. (1995), “Alumni donations and colleges' development expenditures: Does spending mater?" American Journal of Economics and Sociology, 54, pp. 397-412.

House, M.L. (1987), "Annual fund raising in public higher education: the development and validation of a prediction equation," Doctoral dissertation, University of Florida.

Hueston, F.R. (1992), "Predicting alumni giving: A donor analysis test," Fundraising Management, 22 , pp. 19-22.

Keller, M.J. (1982), “An analysis of alumni donor and non-donor characteristics of at the University of Montevallo,” Doctoral dissertation, University of Alabama.

Koral, M.J. (1998), "Political performance: If you want campus support form legislators, alumni volunteers are instrumental to your success," CASE Currents, 24, pp. 46-52.

Korvas, R.J. (1984), “The relationship of selected alumni characteristics and attitudes to financial support at a private college," Doctoral dissertation, University of Toledo.

Leslie, L. and Ramey, G. (1988), "Donor behavior and voluntary support for higher education institutions," Journal of Higher Education, 59, 2, pp. 115-132.

Loessin, B.A., Duronio, M.A. and Borton, G.L. (1986), "Measuring and expanding sources of private funding," in J.A. Dunn (ed.), Enhancing the Management of Fundraising, Jossey-Bass, San Francisco.

Mael, F. and Ashforth, B. (1992), "Alumni and their alma mater: A partial test of the reformulated model of organizational identification," Journal of Organizational Behavior, 13, pp. 103-123.

Miracle, W.D. (1977), "Differences between givers and non-givers to the University of Georgia annual fund," Doctoral dissertation, University of Georgia.

Monks, J. (2003, April), "Patterns of giving to one's alma mater among young graduates from selective institutions," Economics of Education Review, 22, 2, pp. 121-130.

Olsen, K., Smith, A.L. and Wunnava, P.V. (1989), "An empirical study of the life-cycle hypothesis with respect to alumni donations," American Economist, 33, 2, pp. 60-63.

Okunade, A.A. (1996), "Graduate school alumni donations to academic funds-micro data evidence," American Journal of Economics and Sociology, 55, pp. 213-229.

Okunade, A.A. and Berl, R.L. (1997), "Determinants of charitable giving of business school alumni," Research in Higher Education, 38, pp. 201-214. 
Pendel, M. (1985), “Beyond Gallup,” CASE Currents, 11, 8, pp. 40-42.

Pearson, J. (1999), "Comprehensive research on alumni relationships: Four years of market research at Stanford University," New Directions for Institutional Research, 101, pp. 5-21.

Philanthropic Research, Inc (1996), Guidestar Newsletter. Available online: http://www. guidestar.org/news/features/women.jsp.

Pike, G.R. (1994), "The relationship between alumni satisfaction and work experiences," Research in Higher Education, 35, 1, pp. 105-124.

Rusbult, C.E. (1980), “Commitment and satisfaction in romantic associations: A test of the investment model," Journal of Experimental Social Psychology, 16, pp. 172-186.

Shadoian, J.L. (1989), “A study of predictors of alumni donors in public colleges," Doctoral dissertation, University of Connecticut).

Shaw, S.C. and Taylor, M.A. (1995), Reinventing Fundraising. Realizing the Potential of Women's Philanthropy, Jossey-Bass, San Francisco.

Sturtevant, W. (2002), "Major gifts fundraising: The mission and promise," Keynote address at the Annual Association for Arts and Sciences Advancement Professionals Meeting, Pittsburgh, June 4, 2002.
Taylor, A.L. and Martin, J.C. (1995), "Characteristics of alumni donors and nondonors at a research I, public university," Research in Higher Education, 36, 3, pp. 283-302.

Thomas, J.A. and Smart, J.C. (2005), “The relationship between personal and social growth, involvement in college and subsequent alumni giving," Paper presented at the meeting of the Association for Institutional Research. San Diego, CA, May 28-June 1.

Volkwein, J.F., Webster-Saft, L., Xu, W. and Agrotes, M.H. (1989, May), "A model of alumni gift giving behavior," Paper presented at the meeting of the Annual Forum of the Association for Institutional Research. Baltimore, MD.

Vroom, V.H. (1964), Work and Motivation, Wiley, New York.

Weerts, D.J. (1998), "Back on track: Seven strategies to get your alumni board moving again," CASE Currents, 24, pp. 35-37.

Wunnava, P.V. and Lauze, M.A. (2001), "Alumni giving at a small liberal arts college: evidence from consistent and occasional donors," Economics of Education Review, 20, pp. 533-543.

Zuzanek, J. and Smale, B.J.A. (1999), "Life- cycle and across the week allocation of time to daily activities," in W.E. Pentland, A.S. Harvey, M.P. Lawton and M. McColl (eds.), Time Use Research in the Social Sciences, Kluwer, New York. 